\title{
Ethnomycological knowledge of wild edible mushrooms in Tlayacapan, Morelos
}

\section{Álvarez-Farias $\mathrm{ZJ}^{\mathbf{1}}$, Díaz-Godínez $\mathrm{G}^{\mathbf{2}}$, Téllez-Téllez $\mathrm{M}^{\mathbf{1}}$, Villegas $\mathrm{E}^{3}$ and Acosta- Urdapilleta $\mathrm{ML}^{1}$}

${ }^{1}$ Centro de Investigaciones Biológicas, Universidad Autónoma del Estado de Morelos, Cuernavaca Morelos, México. maura.tellez@uame.mx,urdapilletal@yahoo.com

${ }^{2}$ Centro de Investigación en Ciencias Biológicas, Universidad Autónoma de Tlaxcala, Tlaxcala, México. diazgdo@hotmail.com

${ }^{3}$ Centro de Investigación en Biotecnología, Universidad Autónoma del Estado de Morelos, Cuernavaca Morelos. elbav@uaem.mx

Álvarez-Farias ZJ, Díaz-Godínez G, Téllez-Téllez M, Villegas E, Acosta-Urdapilleta ML 2016 Ethnomycological knowledge of wild edible mushrooms in Tlayacapan, Morelos. Mycosphere 7(10), 1491-1499, Doi 10.5943/mycosphere/si/3b/1

\begin{abstract}
Different species of wild edible mushrooms are known in Mexico, which are harvested for consumption or sale in the weekly markets or street markets. Collectors have important knowledge of these species, then, the aim of this study was to determine which species are sold in the market and street markets of the town of Tlayacapan, Morelos. From June to November 2012, mushroom sellers were surveyed monthly to collate data regarding the physical characteristics used to identify mushrooms, as well as their common names. Eleven genus of edible fungi were obtained from weekly markets or street markets and a total of 10 species of wild edible mushrooms were identified, of which the phenology and ecology was determined. Pleurotus djamor y Pleurotus djamor var. roseus species are fungi that represent more cultural significance to the community as they were the most frequently occurring species (98.8\%). They had seven different common names and are related to the beginning and the end of the rainy season. This information contributes greatly to the knowledge regarding the region and its culture.
\end{abstract}

Key words - Edible mushroom - fungi - Mexico

\section{Introduction}

Knowledge of the worlds resources including their source and use is important to each culture and environment. As a result, the proposal of sustainable use has increasing importance. However, this term has been used more in political discourse, leaving much to be done on the subject. Many researchers are increasingly involving communities where the biocultural wealth exists. In this sense, ethnomycology as part of ethnobiology, tries to understand the relationship between man and his environment as well as their actions on the environment, impacts and possible solutions where fungi are involved, in different geographical areas, (Henao 2005). Mexico has a high diversity of fungal species and it is estimated that there are about 2400 species of Ascomycetes and 2200 species of Basidiomycetes, of which about 300 wild species are consumed in rural communities (Garibay-Orijel et al. 2006), however, there are few studies on 
ethnomycology, considering that there are about 60 ethnic groups living in the country (MorenoFuentes et al. 2001).

Edible mushrooms have been used since prehispanic times as food, as stimulants and to cure diseases mainly related to rituals and spiritual aspects (Guzmán 2008). They have also been used in modern medicine because they contain properties useful in therapeutic treatments (Barros et al. 2008). In Mexico, the marketing of wild edible mushrooms is an activity that generates significant financial benefits for collectors (Mariaca-Méndez et al. 2001, Estrada-Martínez et al. 2009), who in most cases belong to communities of poor resources and have competition of the marketing of cultivated mushrooms (Martínez-Carrera et al. 2005). This is a widespread phenomenon in areas that have a traditional mycological knowledge, where wild mushrooms are collected for consumption or sale in the weekly markets or street markets, which is important for distribution (Mariaca-Méndez et al. 2001). The collection of edible mushrooms is a family activity, which is done by the father, mother and children (Montoya et al. 2008, Pérez-Moreno et al. 2008).

The mushrooms are sold directly in street markets by the mothers (Ruan-Soto et al. 2006). The economic value of this resource is determined by the species and the date of marketing (Cinta et al. 1998). Recollection of mushrooms for sale, depends mainly on the supply and demand in order to obtain a profitable gain according at invert time for the collectors (transfer from home to the forest and vice versa) (Estrada-Martínez et al. 2009). However, this tradition and the number of species are gradually losing due to the destruction of forested regions of the country and the process of transculturation that are being subjected the ethnic groups (Villarreal \& Pérez-Moreno 1989). The aim of this work is to compile the traditional mycological knowledge among residents of the town of Tlayacapan including practices of use and exploitation of the wild edible fungi of the region.

\section{Materials \& methods}

\section{Description of the study area}

The town of Tlayacapan has an area of $52,136 \mathrm{~km}^{2}$, accounting for $1.05 \%$ of the state. It is located in the north eastern part of the state of Morelos; between parallels $18^{\circ} 57^{\prime} 20^{\prime \prime}$ north latitude and $98^{\circ} 58^{\prime} 52^{\prime \prime}$ longitude west. Its boundaries are: the city of Tlalnepantla is to the north; with the city of Yautepec to the south; the towns of Totolapan and Atlatlahucan are to the east; and the town of Tepoztlan is to the west. Approximate distance to the state capital is $60 \mathrm{~km}$.

The town of Tlayacapan is characterized by having in its central part at three colonies: Santa Ana, El Rosario and Texcalapan, and 14 colonies in the periphery. Orography: It is surrounded by a chain of hills: to the south is the hill of the "Ventanita", the "Sombrerito" or "Yacatl" (nose); on the west is the hill of "Huixtlalzink", "Tlatoani" and "Ziualopapalozink" (lady little butterfly), the highest is $2150 \mathrm{~m}$ high, on the northwest is the hill of "Tezontlala", "Cuitlazimpa" and "Tepozoco"; and to the north is the hill of "Amixtepec", at an altitude of $1630 \mathrm{~m}$. Climate: It is sub humid temperate, with summer rains. Its average temperature is $16^{\circ} \mathrm{C}$. Vegetation: transitional associations of deciduous forest and coniferous forest and oak (Rzedowski 1986). There are some secondary associations derived from the types of vegetation above mentioned. The most common tree species are: Quercus glabrescens, Quercus glaucoides, Pinus teocote and Arbutus xalapensis and shrubs represented by Acacia angustissima, Salvia purpurea, Malvaviscus arboreus (Cerros-Tlatilpa \& Espejo-Serna 1998).

\section{Cultural and ethnomycological significance of wild edible mushrooms}

Monthly visits (June-November 2012) were conducted in the rainy season (EstradaMartínez et al. 2009) at the street markets (culturally inherited by Nahuatl), where the fungi are sold. Based on information gathered during visits, the ethnomycological significance of fungi was determined. To determine the average price per $\mathrm{kg}$, samples of each species were purchased (heap, piece or bag) three times, the weights of which were recorded in the laboratory at the return to fieldwork. To determine the cultural significance of fungi on the settlers of Tlayacapan, frequency 
of mention was used by the informants of the three colonies of Tlayacapan. Approximately 100 surveys were conducted in total (33\% in each colony). Surveys were applied to 5\% of the population of each colony (Estrada-Martínez et al. 2009). The Mention Index (QI), is the ratio of the total number of mentioned fungi divided by the Total Number of interviewees expressed as a percentage $\left(\mathrm{QI}=\mathrm{N}^{\circ}\right.$ mentions/Noinformants*100) (Pieroni 2001). The result shows the position of the taxa within the sample of interviewed persons in the community. The phenology of wild edible mushrooms was established based on the records obtained in the street markets. The assignment of species was supported by a catalog of photographs of fungi in the region, with which their taxonomic identity was also confirmed. When people mentioned the same name for several species, it was assigned to the one that received the most mentions in the community.

\section{Taxonomic identification}

The taxonomic identification of fungi samples acquired in the markets was based on registration data of fresh mushrooms. The data recorded the color of all parts of the fruiting body including its interior, color changes after being cut or damaged, study of the fertile surface (hymenium), presence and position of the foot, veil, ring and volva of flakes on surfaces and color of the spore when possible to obtain. On the same day of purchase, the fresh fungi were photographed and all data recorded. Species identification was determined with the help of a mycologist and specialist literature (Herrera \& Guzmán 1961, Guzmán 1978, 1979, Breitenbach \& Kränzlin 1981, 1991, Pegler 1983, Bon 1987, Guzmán \& Tapia 1998, Index Fungorum 2016). Some mushrooms were indicated only as sp. by their taxonomic complexity, such as Ramaria, Xeromphalina and Hygrophorus.

\section{Results}

\section{Identification of species of wild mushrooms purchased}

A total of 10 species were identified (three mushrooms were identified only at the genus level). These included 11 genus of fungi of Phylum Basidiomycota in the town of Tlayacapan, belonging to five different orders (Agaricales, Boletales, Cantharellales, Gomphales and Russulales) and to 11 families (Table 1). Pleurotaceae and Gomphaceae families, had two species each, the rest of the families were represented with one species. Within the mushrooms consumed in this population two non-wild edible species were identified (Ustilago maydis (D.C.) Corda and Agaricus bitorquis (Quél.) Sacc.). Informants reported the harvest of Lactarius indigo and Collybia dryophila, which are sold and consumed in the five major markets of Morelos, however, in the community of Tlayacapan, these mushrooms are not eaten.

Table 1 Taxonomy of the species recorded.

\begin{tabular}{llll}
\hline Phylum & Order & Family & Scientific name \\
\hline Basidiomycota & Agaricales & Pleurotaceae & Pleurotus djamor (Rump.ex Fr.) Boedijn \\
& & Pleurotus djamor var. roseus Corner \\
& & Pluteaceae & Volvariella bombycina (Schaeff.) Singer \\
& Amanitaceae & Amanita caesarea (Scop.) Pers. \\
& Hygrophoraceae & Hygrophorus sp. \\
& Mycenaceae & Xeromphalina sp. \\
& Lyophyllaceae & Lyophyllum decastes (Fr.) Singer \\
& Boletales & Boletaceae & Boletus edulis Bull. \\
& Suillaceae & Suillus granulatus (L.) Roussel \\
& Cantharellales & Cantharellaceae & Cantharellus cibarius Fr \\
& Gomphales & Gomphaceae & Ramaria sp. \\
& & Ramaria botrytis (Pers.) Ricken \\
& & Russula brevipes Peck \\
\hline
\end{tabular}




\section{Traditional mycological knowledge of the colonies in the town of Tlayacapan}

Most people (80\% of respondents) of Tlayacapan, recognized the mushrooms as food, $7 \%$ believed that the mushrooms are plants, $6 \%$ of the population believed that the mushrooms are a vegetable, $5 \%$ defined the mushrooms as an organism, $1 \%$ defined mushrooms as a product of the field and $1 \%$ could not define what a mushroom was. The ethnomycological knowledge is mainly transmitted by parents (mom or dad) to children $(58 \%)$ or young $(42 \%)$, as most learned to collect mushrooms as children and young. The color, shape and smell of the mushrooms are the main criteria mentioned by Tlayacapan residents to recognize mushrooms called "good" (edible). In the three colonies of the town of Tlayacapan, it was mentioned that, their families used to eat mushrooms from the mountain at any time of year. This suggests the existence of a mycophilic culture in the study area. From the colony of Rosario informants reported 22 different traditional names of edible mushrooms, the colony of Texcalpan recognizes 10 common names while the colony of Sta. Ana contributed six different traditional names of edible mushrooms (Table 2).

Table 2 Common names of edible mushroom species identified in the three colonies of Tlayacapan.

\begin{tabular}{|c|c|c|c|}
\hline \multirow[t]{2}{*}{ Species } & \multicolumn{3}{|c|}{ Colonies } \\
\hline & Santa Ana & Texcalpan & Rosario \\
\hline Amanita caesarea & Huevito & Huevo, Huevito & Huevo, Huevito, Amarillo \\
\hline Boletus edulis & Pancita & Pancita & Pancita \\
\hline Canthalerus cibarius & & & Amarillo \\
\hline Collybia dryophila & & & \\
\hline Hygrophorus sp. & & & \\
\hline Lactarius indigo & & & Hongo azul \\
\hline Lyophyllum decastes & Clavitos & Clavitos & Clavitos, Clavo, Clavillo \\
\hline Pleurotus djamor & Seta & $\begin{array}{l}\text { Seta, Cazahuate, } \\
\text { Orejón }\end{array}$ & $\begin{array}{l}\text { Hongo de pino, seta, } \\
\text { cazahuate, orejón, Blanco, } \\
\text { oreja de cazahuate }\end{array}$ \\
\hline Pleurotus djamor var. roseus & & & Hongo rosa \\
\hline Ramaria botrytis & Escobeta & Escobeta & Escobeta, Escobetilla \\
\hline Ramaria sp. & Escobetilla & Escobilla & Escobilla \\
\hline Rusula brevipes & & & Blanco \\
\hline Suillus granulatus & & & \\
\hline Volvariella bombycina & & & Amarillo \\
\hline Xeromphalina sp. & & & Sombrerito \\
\hline Common names registered & 6 & 10 & 22 \\
\hline
\end{tabular}

It is important to note that in the colony of Rosario, $P$. djamor is the edible fungi with the most names, it is known as "oreja de cazahuate", "orejón", "cazahuate", "blanco", "hongo de pino" and "seta". L. decastes is known by three names: "clavito", "clavo" and "clavillo". Ramaria sp. and A. caesarea have three common names, other edible mushrooms are known by a single traditional name. QI values were between $98.8 \%$ and $1.17 \%$, Pleurotus shows $98.8 \%$, followed by "clavitos" (L. decastes) and "escobetas" (Ramaria sp. and R. botrytis) with $64.7 \%$ and $47 \%$ respectively, the species less mentioned were $C$. cibarius, $V$. bombycina and $R$. brevipes.

\section{Importance of mushroom sales in the street markets of Tlayacapan}

Twelve species of edible mushrooms (Table 1) were registered in the street markets. By studying phenology of mushrooms (Table 3), $P$. djamor and $P$. djamor var. roseus (commonly known as "setas") were identified as the edible mushroom most mentioned by the people of Tlayacapan. This mushroom marks the beginning of the season and is collected in the first rains, which in this region is between the months of May and June. These species were observed over seven months (May to October). Mushrooms A. caesarea, C. cibarius and Hygrophorus sp. were recorded for three months (July to September), but these were present in the market from June to August. 
Table 3 Phenology of edible mushroom species studied in the three colonies of Tlayacapan.

\begin{tabular}{|c|c|c|c|c|c|c|c|}
\hline Specie & May & Jun & Jul & Aug & Sep & Oct & Nov \\
\hline Amanita caesarea & & & $\mathrm{x}$ & $\mathrm{x}$ & $\mathrm{x}$ & & \\
\hline Boletus edulis & & $\mathrm{x}$ & $\mathrm{x}$ & $\mathrm{x}$ & $\mathrm{x}$ & & \\
\hline Cantharellus cibarius & & & $\mathrm{x}$ & $\mathrm{x}$ & $\mathrm{x}$ & & \\
\hline Hygrophorus sp. & & $\mathrm{x}$ & $\mathrm{x}$ & $\mathrm{x}$ & & & \\
\hline Lyophyllum decastes & & $\mathrm{x}$ & $\mathrm{x}$ & $\mathrm{x}$ & $\mathrm{x}$ & & \\
\hline Pleurotus djamor & $\mathrm{x}$ & $\mathrm{x}$ & $\mathrm{x}$ & $\mathrm{x}$ & $\mathrm{x}$ & $\mathrm{x}$ & $\mathrm{x}$ \\
\hline Pleurotus djamor var. roseus & $\mathrm{x}$ & $\mathrm{x}$ & $\mathrm{x}$ & $\mathrm{x}$ & $\mathrm{x}$ & $\mathrm{x}$ & $\mathrm{x}$ \\
\hline Ramaria sp. & & $\mathrm{x}$ & $\mathrm{x}$ & $\mathrm{x}$ & $\mathrm{x}$ & $\mathrm{x}$ & \\
\hline Ramaria botrytis & & $\mathrm{x}$ & $\mathrm{x}$ & $\mathrm{x}$ & $\mathrm{x}$ & $\mathrm{x}$ & \\
\hline Russula brevipes & & $\mathrm{x}$ & $\mathrm{x}$ & $\mathrm{x}$ & $\mathrm{x}$ & & \\
\hline Suillus granulatus & & $\mathrm{x}$ & $\mathrm{x}$ & $\mathrm{x}$ & $\mathrm{x}$ & & \\
\hline Xeromphalina sp. & & $\mathrm{x}$ & $\mathrm{x}$ & $\mathrm{x}$ & $\mathrm{x}$ & & \\
\hline Volvariella bombycina & $\mathrm{x}$ & $\mathrm{x}$ & $\mathrm{x}$ & $\mathrm{x}$ & & & \\
\hline \multicolumn{8}{|c|}{ Found in the local forest } \\
\hline Collybia dryophila & & & $\mathrm{x}$ & & & & \\
\hline Lactarius indigo & & & $\mathrm{x}$ & & & & \\
\hline \multicolumn{8}{|c|}{ Cultivated mushrooms } \\
\hline Agaricus bitorquis & $\mathrm{x}$ & $\mathrm{x}$ & $\mathrm{x}$ & $\mathrm{x}$ & $\mathrm{x}$ & $\mathrm{x}$ & $\mathrm{x}$ \\
\hline Ustilago maydis & $\mathrm{x}$ & $\mathrm{x}$ & $\mathrm{x}$ & $\mathrm{x}$ & $\mathrm{x}$ & $\mathrm{x}$ & $\mathrm{x}$ \\
\hline
\end{tabular}

It was not possible to establish the phenology of L. indigo ("hongo azul") and C. dryophila because these species are non-edible mushrooms in the community, so they are not collected. $L$. indigo is not eaten because of its intense blue color (selection criteria by collectors of the community). U. maydis and A. bitorquis were found in the market throughout the year, because they are cultivated mushrooms.

The species represent an important cultural wealth of the region by the demand for them through a reiteration of traditional knowledge among buyers. The price (Mexican pesos " $\$$ ") of the mushrooms varies depending on the species, unit of sale and season (Table 4). $50 \%$ of respondents in the three colonies mentioned that mushrooms are obtained for consumption by collecting, $30 \%$ replied that mushrooms were obtained by purchasing and the rest did not answer.

Table 4 Unit of sale and price of mushrooms in the market of Tlayacapan.

\begin{tabular}{|c|c|c|c|c|c|}
\hline Scientific name & Common name & Kilo (\$) & Heap (\$) & Bag (\$) & Piece (\$) \\
\hline Amanita caesarea & Huevo & $30-35$ & $15-25$ & 20 & \\
\hline Boletus edulis & Pancita & & & & $15-35$ \\
\hline Cantharellus cibarius & Amarillo & & $25-30$ & & \\
\hline Hygrophorus sp. & & & $25-30$ & & \\
\hline Lyophyllum decastes & Clavitos & $30-35$ & 25 & & 15 \\
\hline Pleurotus djamor & Cazahuate & $35-80$ & $25-65$ & $15-25$ & \\
\hline Pleurotus djamor var. roseus & Hongo rosa & & & & \\
\hline Ramaria botrytis & Escobeta & $35-40$ & $20-60$ & 20 & \\
\hline Ramaria sp. & Escobeta & $35-40$ & $20-60$ & 20 & \\
\hline Russula brevipes & Blanco & & 35 & & \\
\hline Suillus granulatus & Pancita & & & & $15-35$ \\
\hline Volvariella bombycina & Amarillo & & $25-30$ & & \\
\hline Xeromphalina sp. & Sombrerito & & $25-30$ & & \\
\hline Agaricus bitorquis & Champiñón & 75 & & & \\
\hline Ustilago maydis & Huitlacoche & $25-40$ & & & \\
\hline
\end{tabular}

Some species of mushrooms were observed a few times during the rainy season 2013 in the community. The "pancitas" were less abundant during the season, followed by the "huevos", "clavitos" and "escobetas" (Figs. 1-12). 


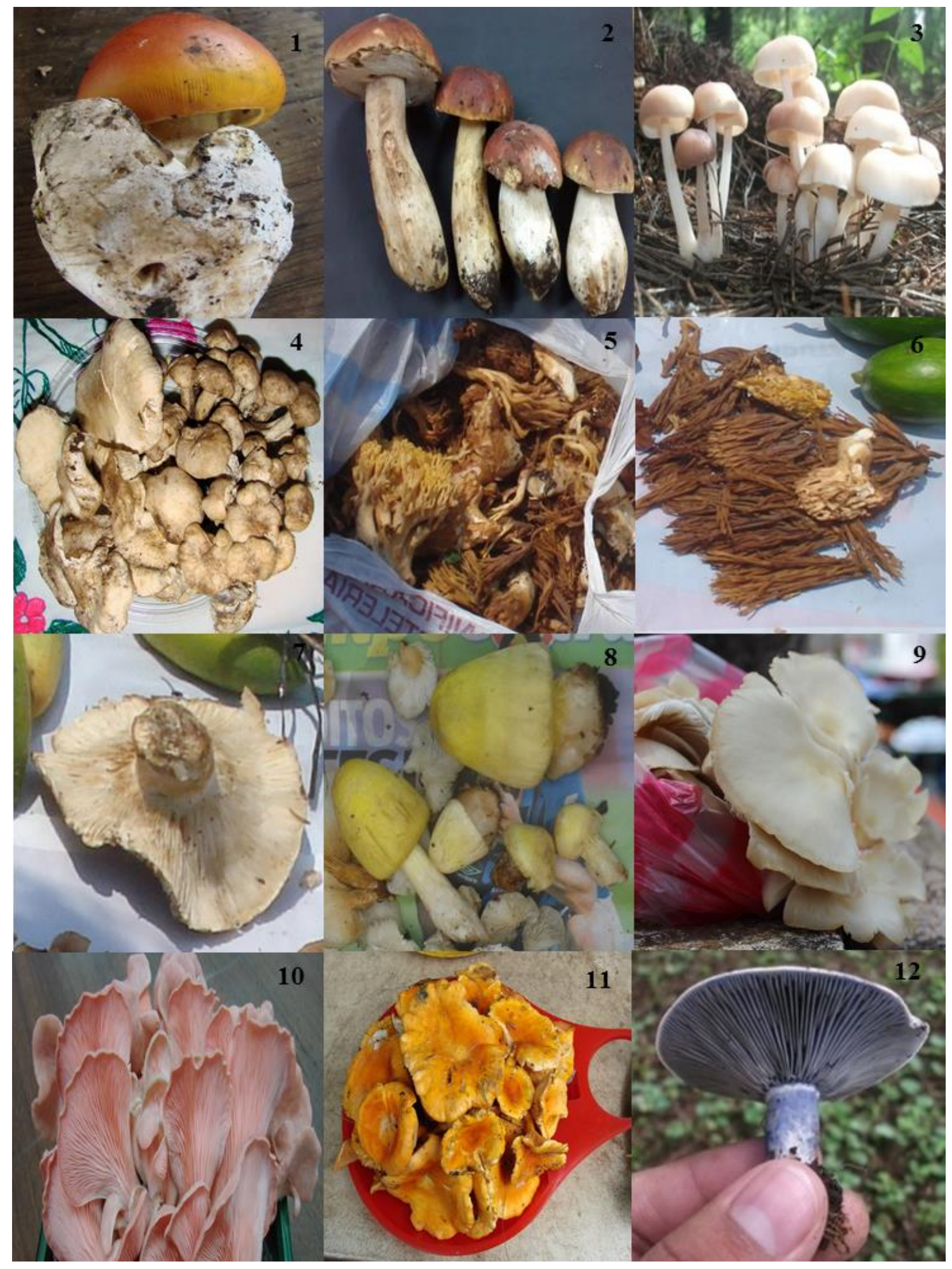

Figs 1-12 - Wild edible mushrooms of Tlayacapan, Morelos. 1. A. caesarea. 2. B. edulis. 3. C. dryophila. 4. L. decastes 5. R. botrytis. 6. Ramaria sp. 7. R. brevipes. 8. V. bombycina. 9. P. djamor. 10. P. djamor var. roseus. 11. C. cibarius. 12. L. indigo. 


\section{Discussion}

Macromycetes wild species that are eaten in the state of Morelos are collected based on the ethnomycological knowledge of the people, and they are sold to local consumers depending on seasonal availability. Mora et al. (1990) reported 38 species of edible mushrooms in a study conducted in six major markets in the state of Morelos, Portugal et al. (2010) identified 45 species of edible mushrooms in five markets in the state of Morelos.

Alpuche \& Aguilar (2010) reported that through the perception of odor and color, collectors recognize edible or non-edible fungi; Hernández (2007) made similar reports, however the color stands as the most important characteristic for identification. It is important to note that ethnomycological knowledge is mainly transmitted by parents (mom or dad) to children (58\%). This coincides with many studies, where they mention that boys learn to collect mushrooms in the forest and women taught the girls to identify and cook them (Mariaca-Méndez et al. 2001, Alpuche \& Aguilar 2010, Rodríguez-Muñoz 2012).

In this study $P$. djamor was the mushroom with the highest IQ value, however, GaribayOrijel et al. (2007) reported that in Ixtlan Oaxaca, the mushrooms least mentioned were species of Pleurotus (approximately 4\%) among others and the mushrooms with high IQ value were $A$. caesarea, Ramaria spp. and A. pampeanus (>50\%). Estrada-Martínez et al. (2009) reported that $L$. decastes and A. caesarea were the species with higher IQ values (68\% and $50 \%$ respectively) in markets from Sierra Nevada of Mexico.

$50 \%$ of respondents in the three colonies mentioned that mushrooms are obtained for consumption by collecting. Vázquez-García \& Montes-Estrada (2006) considered that the mushroom collection is linked to the whole process of the rural community and in support of the economic crisis so mushrooms collected are offered in different markets. Hernández (2007) and Rodríguez-Muñoz et al. (2012), mentioned that mushroom collection is mainly oriented to consumption which coincides with the results obtained in this work.

The observations in this study for Pleurotus species suggest that the selling price is moderate possibly due to their abundance, a factor that also contributes to their cultural significance (Montoya et al. 2003). Burrola-Aguilar et al. (2012) reported the sale of wild edible mushrooms in the state of Hidalgo, and found that the price of various mushrooms was from \$25 (Ramaria spp.) to $\$ 250$ (Morchella spp.) per kilogram, depending on the fungus. The sales unit called a stack was the most common followed by sales per kilogram. Mushrooms sold in bags had less prominence and very few marketers use the sales unit by piece. The mushrooms sold per piece were "clavitos" (L. decastes) and "pancita" (B. edulis). Furthermore, the unit sale per bag is used mainly for the sale of "cazahuate", "escobeta and "huevo" (Table 4). It has been reported that in Meghalaya, India about 11 different macromycetes species are consumed and the price in the market are of 200-350 rupees/kg ; Clavulina spp. was the most expensive variety sold (300-350 rupees/kg) throughout the period of sale, it was sold in all local markets and was available in fresh and dried forms (Khaund \& Joshi 2013).

Twenty four traditional names of edible mushrooms in the three colonies of Tlayacapan, Morelos were obtained, of which 10 species belonging to 11 genus were identified. Mushrooms are considered an important source of food for people in the region. The species most frequently mentioned was $P$. djamor and $P$. djamor var. roseus, which are culturally important species. The mushroom L. indigo ("hongo azúl") is not consumed, because of their color and C. dryophila also is not considered edible in this town.

This study coincides with the reports of the existence of cultural diversity in the use of mycotic resources (Estrada-Martínez et al. 2009). Garibay-Orijel et al. (2006) reported that in Ixtlan, Oaxaca the mushroom Boletus pinophilus is a species not consumed by the Zapotecs, and several etnomicológicos studies in central Mexico reported this species as edible (Tovar \& Valenzuela 2006) and was mentioned by more than $95 \%$ of the population of three communities of the Malinche volcano in Mexico (Montoya et al. 2002). The ethnomicological knowledge which is inherited through generations is valuable culturally so it is important that is is retrieved and documented by systematics. 


\section{Acknowledgements}

Thanks to the MSc. Elizur Montiel Arcos for the support in the identification of species.

\section{References}

Alpuche O, Aguilar W. 2010 - Capítulo 16: Recolección de hongos de cazahuate e identidad cultural en comunidades del sur de Tepoztlan In Diversidad, conservación y manejo en el corredor biológico Chichinautzin. J.R. Bonilla-Barbosa, V.M. Mora, J. Luna-Figueroa, H. Colín, S. Santillan-Alarcón. Universidad Autónoma del Estado de Morelos Press, México. pp. 229-241.

Barros L, Cruz T, Baptista P, Estevinho LM, Ferreira ICFR. 2008 - Wild and commercial mushrooms as source of nutrients and nutraceuticals. Food and Chemical Toxicology 46, $2742-2747$.

Bon M. 1987 - The Mushrooms and Toadstools of Britain and North Western Europe. Hodder and Stoughton, Londres, RU. pp 352.

Breitenbach J, Kränzlin F. 1981 - Fungi of Switzerland. Vol. 1. Ascomycetes. Mykologia. Lucerna, Suiza. pp 310.

Breitenbach J, Kränzlin F. 1991 - Fungi of Switzerland. Vol. 3. Mykologia. Lucerna, Suiza. 361.

Burrola-Aguilar C, Montiel O, Garibay-Orijel R, Zizumbo-Villarreal L. 2012 - Conocimiento tradicional y aprovechamiento de los hongos comestibles silvestres en la región de Amanalco. Estado de México. Revista Mexicana de Micología 35, 1-16.

Cerros-Tlatilpa R, Espejo-Serna A. 1998 - Contribución al estudio florístico de los cerros El Sombrerito y Las Mariposas (Zoapapalotl) en el municipio de Tlayacapan, Morelos, México. Polibotánica 8, 29-46.

Cinta I, Hernández A, Salas I, Romo E. 1998 - Los hongos comestibles silvestres: una alternativa para el desarrollo regional. Gaceta Ecológica de SEMARNAT 48, 27-34.

Estrada-Martínez E, Guzmán G, Cibrián-Tovar D, Ortega R. 2009 - Contribución al conocimiento etnomicologíco de los hongos comestibles silvestres en mercados regionales y comunidades de la Sierra Nevada (México). Interciencia 34, 25-33.

Garibay-Orijel R, Caballero J, Estrada-Torres A, Cifuentes J. 2007 - Urderstanding cultural significance, the edible mushrooms case. Journal of Ethnobiology and Ethnomedicine 3, 4.

Garibay-Orijel R, Cifuentes J, Estrada-Torres A, Caballero J. 2006 - People using macrofungal diversity in Oaxaca, México. Fungal Diversity 21, 41-64.

Guzmán G, Tapia F. 1998 - The known morels in Mexico, a description a new blushing species, Morchella rufobrunnea and new data on M. guatemalensis. Mycologia 90, 705-714.

Guzmán G. 1978 - Hongos. Limusa. México, DF, México.

Guzmán G. 1979 - Identificación de los hongos comestibles, venenosos, alucinantes y destructores de la madera. Editorial Limusa México.

Guzmán G. 2008 - Hallucinogenic Mushrooms in Mexico: An Overview. Economic Botany 62, 404-412.

Henao LG. 2005 - Etnomicetología. Acta Biológica Colombiana 10, 75-78.

Hernández H. 2007 - Macromicetos de una región de Mineral del Chico, Hidalgo: una aproximación a la etnomicología. Tesis de licenciatura. Instituto de ciencias básicas e ingeniería área académica de biología. Mineral del Chico, Hidalgo.

Herrera T, Guzmán G. 1961 - Taxonomía y ecología de los principales hongos comestibles de diversos lugares de México. Anales del Instituto de Biología, UNAM 32, 33-135.

Khaund P, Joshi SR. 2013 - Wild edible macrofungal species consumed by the Khasi tribe of Meghalaya, India. Indian Journal of Natural Products and Resources 4, 197-204.

Mariaca-Méndez R, Silva-Pérez LC, Castaños-Montes CA. 2001 - Proceso de recolección y comercialización de hongos comestibles silvestres en el Valle de Toluca, México. Ciencia Ergo Sum, Universidad Autónoma del Estado de México 8, 30-40. 
Martínez-Carrera D, Nava D, Sobal M, Bonilla M, Mayett Y. 2005 - Marketing channels for wild and cultivated edible mushrooms in developing countries: the case of México. Micología Aplicada Internacional 17, 9-20.

Montoya A, Estrada-Torres A, Caballero J. 2002 - Comparative ethnomicological survey of three localities from La Malinche Volcano, Mexico. Journal of Ethnobiology 22, 103-131.

Montoya A, Hernández N, Mapes C, Kong A, Estrada-Torres A. 2008 - The collection and sale of wild mushrooms in community of Tlaxcala, Mexico. Economic Botany 62, 413-424.

Montoya A, Hernández-Totomoch O, Estrada-Torres A, Kong A, Caballero J. 2003 - Traditional knowledge about mushrooms in a Nahua community in the state of Tlaxcala, Mexico. Mycologia 95, 793-806.

Mora V, López-Eustaquio L, Bautista N, Portugal D, Montiel E. 1990 - Hongos comestibles silvestres que se venden en los principales mercados del estado de Morelos. Universidad Ciencia y Tecnología (UAEM, México) 1, 21-26.

Moreno-Fuentes A, Garibay-Orijel R, Tovar-Velazco JA, Cifuentes J. 2001 - Situación actual de la etnomicología en México y el mundo. Etnobiologia 1, 75-84.

Pegler DN. 1983 - Agaric flora of the Lesser Antilles. Kew Bulletin Additional Series. 9. Her Majesty's Station Office. Londres, RU. 668.

Pérez-Moreno J, Lorenzana-Fernández A, Carrasco-Hernández V, Yescas-Pérez A. 2008 - Wild mushroom markets in central Mexico and a case study at Ozumba. Economic Botany 62, 425-436.

Pieroni A. 2001 - Evaluation of the cultural significance of wild food botanicals traditionally consumed in Northwestern Tuscany, Italy. Journal of Ethnobiology 21, 89-104.

Portugal D, López-Eustaquio L, Mora VM, Bautista N. 2010 - Capítulo 15: Hongos comestibles In Diversidad, conservación y manejo en el corredor biológico Chichinautzin. J.R. BonillaBarbosa, V.M. Mora, J. Luna-Figueroa, H. Colín, S. Santillan-Alarcón. Universidad Autónoma del Estado de Morelos, México. pp. 223-228.

Rodríguez-Muñoz G, Zapata-Matelo E, Rodríguez MN, Vázquez-García V, Martínez-Corona B, Vizcarra-Bordi I. 2012 - Saberes tradicionales, acceso, uso y transformación de hongos silvestres comestibles en Santa Catarina del Monte, estado de México. Agricultura, sociedad y desarrollo 9, 191-207.

Ruan-Soto F, Garibay-Orijel R, Cienfuentes J. 2006 - Process and dynamics of traditional selling wild edible mushrooms in tropical Mexico. Journal of Ethnobiology and Ethnomedicine 2, 113.

Rzedowski J, 1986 - Vegetación de México. Editorial Limusa. 432.

Tovar JA, Valenzuela R. 2006 - Los hongos del Parque Nacional Desierto de los Leones. In Los Hongos del Parque Nacional Desierto de los Leones. JA. Tovar \& R. Valenzuela. Gobierno del Distrito Federal/Secretaría del Medio Ambiente/ Parque Nacional Desierto de los Leones (Eds.). México, DF, México 5, 37-82

Vázquez-García V, Montes-Estrada M. 2006 - Plantas alimenticias no cultivadas en la Sierra de Santa María, Veracruz. Relaciones de género y papel en la dieta cotidiana. Agronuevo 13, 89-122.

Villarreal L, Pérez-Moreno J. 1989 - Los hongos comestibles silvestres de México, un enfoque integral. Micología Neotropical Aplicada 2, 77-11 4.

Index Fungorum 2016 - www.indexfungorum.org 